\title{
Retinoic acid cross-talk with calcitriol activity in Atlantic salmon (Salmo salar)
}

\author{
R Ørnsrud ${ }^{1, *}$, E J Lock ${ }^{1,2, *}$, C N Glover ${ }^{3}$ and G Flik ${ }^{2}$ \\ ${ }^{1}$ National Institute of Nutrition and Seafood Research, PO Box 2029 Nordnes, N-5817 Bergen, Norway \\ ${ }^{2}$ Department of Animal Physiology, Faculty of Science, Institute for Water and Wetland Research, Radboud University Nijmegen, \\ Heyendaalseweg 135, NL-6525 AJ Nijmegen, The Netherlands \\ ${ }^{3}$ School of Biological Sciences, University of Canterbury, Private Bag 4800, Christchurch 8014, New Zealand \\ (Correspondence should be addressed to R Ørnsrud; Email: robin.ornsrud@nifes.no) \\ *(R Ørnsrud and E J Lock contributed equally to this work $)$
}

\begin{abstract}
Vitamins $\mathrm{A}(\mathrm{VA})$ and $\mathrm{D}(\mathrm{VD})$ are metabolised by vertebrates to bioactive retinoic acid (RA) and calcitriol (CTR). RA and CTR involvement in bone metabolism requires finetuned regulation of their synthesis and breakdown. In mammals antagonism of VA and VD is observed, but the mechanism of interaction is unknown. We investigated VAVD interactions in Atlantic salmon (Salmo salar L.) following i.p. injection of RA and/or CTR. VA metabolites, CTR, calcium (Ca), magnesium (Mg) and phosphorus $(\mathrm{P})$ were determined in plasma. Expression of bone matrix Gla protein (mgp), collagen 1 alpha2 chain (col1a2) and alkaline phosphatase (alp) mRNA was quantified to reflect osteogenesis. Branchial epithelial $\mathrm{Ca}$ channel (ecac listed as trpv6 in ZFIN Database) mRNA levels and intestinal $\mathrm{Ca}$ and $\mathrm{P}$ influx were determined to study $\mathrm{Ca} / \mathrm{P}$ handling targets of $\mathrm{RA}$ and CTR.
\end{abstract}

RA-injection (with or without CTR) decreased plasma CTR-levels three- to sixfold. CTR injection did not affect RA metabolites, but lowered CTR in plasma 3 and 5 days after injection. Lowered plasma CTR correlated with decreased mgp and col1a2 expression in all groups and with decreased alp in CTR-injected fish. RA-treated salmon had enhanced alp expression, irrespective of reduced plasma CTR. Expression of ecac and unidirectional intestinal influx of Ca were stimulated following RA-CTR treatment. Plasma $\mathrm{Ca}, \mathrm{Mg}$ and $\mathrm{P}$ were not affected by any treatment. The results suggest cross-talk of RA with the VD endocrine system in Atlantic salmon. Enhanced $\mathrm{Ca}$ flux and osteogenesis (alp transcription) in RA-treated fish and inhibition of $m g p$ expression revealed unprecedented disturbance of $\mathrm{Ca}$ physiology in hypervitaminosis A.

Journal of Endocrinology (2009) 202, 473-482

\section{Introduction}

The fat soluble vitamins $\mathrm{A}(\mathrm{VA})$ and $\mathrm{D}(\mathrm{VD})$ are essential nutrients in the diet of vertebrates. VA is crucial for vision, growth, reproduction and embryological development. VD is deeply involved in calcium $(\mathrm{Ca})$ and phosphorus $(\mathrm{P})$ homeostasis through modulation of $\mathrm{Ca}$ uptake (via gills and intestine in fish, via intestine in higher vertebrates), renal reabsorption, bone deposition/resorption and modulation of the immune response. The main active metabolites of VA and VD are retinoic acid (RA) and calcitriol (CTR; $1 \alpha$, $\left.25(\mathrm{OH})_{2} \mathrm{D}_{3}\right)$ respectively. These metabolites induce biological effects via high-affinity nuclear transcription factors. Genomic actions of CTR are mediated by the VD receptor (VDR), while RA binds to either a RA receptor (RAR) or retinoid $X$ receptor ( $R X R$ ). The RAR family includes $\operatorname{RAR} \alpha, \operatorname{RAR} \beta$, and $\operatorname{RAR} \gamma$, receptors that show high affinity for the all-trans or 9-cis isomers of RA. The RXR subfamily also consists of three receptor subtypes; $\operatorname{RXR} \alpha, \operatorname{RXR} \beta$ and
$\operatorname{RXR} \gamma$. These differ from RARs in that they preferentially bind 9-cis RA and may act as 'silent partners', i.e. without ligand binding. VDRs, RXRs and RARs require dimerisation for activity (e.g. RAR-RXR or VDR-RXR). After binding ligands and undergoing dimerisation, the receptorligand complexes associate with specific DNA response elements (VD response elements, VDRE; RA response elements, RARE) to activate or suppress gene transcription. Indeed, interactions between CTR and retinoids are indicated as the VDR acts as a heterodimer with the RXR. The use of RXR as a DNA-binding facilitator places VDR in a receptor class that also includes the thyroid hormone receptors, the peroxisome proliferator-activated receptor (PPAR; Pathrose et al. 2002).

Bone is a key target for RA and CTR. In fish, CTR exerts effects directly on both osteoblasts and osteoclasts (Wendelaar Bonga et al. 1983). Chronic CTR exposure increases bone formation, but may also impair mineralisation, at least in rats (Wronski et al. 1986). Short-term exposure of CTR induced 
similar effects, with an elevated number of osteoblasts, increased bone formation, and decreased osteoclast incidence in rat cancellous bone (Erben et al. 1997). CTR is reported to both inhibit and induce expression of collagen-I mRNA, depending on factors such as the species tested, osteoblast differentiation stage, and duration of CTR exposure (Van Leeuwen et al. 2001). CTR induces osteocalcin mRNA expression in human and rat osteoblasts, Mgp mRNA in rat osteoblasts, and osteopontin and alkaline phosphatase $(A l p)$ mRNA in human, rat and mice osteoblasts (Van Leeuwen et al. 2001). In fish, CTR exposure increases mRNA expression of an epithelial Ca channel, (ecac listed as trpv6 in ZFIN Database) in gills (Qiu et al. 2007) and intestinal Ca transport in eel (Fenwick et al. 1984). Available reports on CTR effects in fish are ambiguous with both stimulation and degradation of calcified tissues documented (Wendelaar Bonga et al. 1983, Fenwick et al. 1994). The apparent discrepancies likely result from uncontrolled factors such as $\mathrm{Ca}$ and $\mathrm{P}$ availability and hormone doses used.

Evidence suggests that RA has opposite effects on bone when compared to CTR. RA interferes with a range of osteoblast properties, e.g. inhibition of osteocalcin mRNA expression in mouse osteoblasts (Cohen-Tanugi \& Forest 1998), reduction of collagen mRNA synthesis in rat and chicken osteoblasts (Dickson \& Walls 1985, Kim \& Chen 1989) and increased collagenase mRNA expression and collagen degradation in rat (Varghese et al. 1994). Skeletal deformities in fish have been causally associated with dietary retinol levels (Dedi et al. 1995, Ørnsrud et al. 2002).

Data from mammalian studies indicate that excess VA levels antagonise VD's roles in Ca homeostasis. High VA intake can ameliorate toxic (overdose) effects of VD in rats (Clark \& Bassett 1962), turkey (Metz et al. 1985) and chick (Aburto \& Britton 1998b), and increased requirement for dietary VD has been shown with high levels of dietary VA (Metz et al. 1985, Aburto \& Britton 1998a). In addition to sharing common targets, CTR and RA interact at other levels. For example, RA exhibits direct effects on key genes in the CTR signalling pathway. RA was found to stimulate $V d r$ expression in both tumour and non-tumour bone cells of rats (Petkovich et al. 1986) and mouse (Suzuki et al. 1993). RA also increases the expression of the VD catabolising enzyme $25(\mathrm{OH}) \mathrm{D}_{3^{-}}$ 24-hydroxylase (Cyp24a1; Allegretto et al. 1995), and synergistic effects were shown between RA and CTR in their effect on rat renal CYP24A1 activity (Reinhardt et al. 1999). Frankel et al. (1986) found that chronically VA-overdosed rats had increased osteoclast activity, reduced osteoid formation and reduced circulating levels of $25(\mathrm{OH}) \mathrm{D}_{3}$, and that $\mathrm{VD}$-overdosed animals lowered their serum $\mathrm{Ca}$ and serum $25(\mathrm{OH}) \mathrm{D}_{3}$ after a moderate dose of VA. In a series of studies on rats with varying VD status, reduced serum Ca levels, increased P levels, reduced mineralisation of bones (Rohde et al. 1999, Rohde \& DeLuca 2005) and increased bone resorption (Rohde \& DeLuca 2003) were found as an effect of VA supplementation. A VA dose corresponding to a single serving of liver antagonised the ability of CTR to increase intestinal Ca absorption in human subjects $24 \mathrm{~h}$ post treatment (Johansson \& Melhus 2001). Thus, RA and CTR exhibit complex interactions, reflected in $\mathrm{Ca}$ transport phenomena and aspects of bone turnover.

Intensive aquaculture of Atlantic salmon (Salmo salar) uses formulated diets with high contents of fish meal and fish oil, and thus potentially has excessive amounts of VA. Little if anything is known regarding the effect of VA on VD (and vice versa) in salmon and other fish species.

This study was undertaken to investigate interactions between RA and CTR in Atlantic salmon, to understand the nature of a possible interaction, and to determine any effect on vitamin plasma levels, gene expression of selected bone markers, and $\mathrm{Ca}$ and $\mathrm{P}$ absorption.

\section{Materials and Methods}

\section{Fish and experimental treatment}

Atlantic salmon (Salmo salar L.) 'Sea Farm strain', with an average weight ( \pm S.D.) of $35 \pm 6 \mathrm{~g}$ was obtained from Marine Harvest, Tveitevåg, Norway. The fish were maintained in 160-1 fibreglass tanks with flowing fresh water at $91 / \mathrm{min}$, oxygen content $\sim 10 \mathrm{mg} / \mathrm{l}$ and water temperature $5-7^{\circ} \mathrm{C}$. Fish were fed a commercial diet (Nutra Transfer LB3, Skretting, Norway) until 4 days before experimental treatment. The experiment was approved by the National Animal Research Authority of Norway. There was no mortality or signs of distress among the fish during the trial.

\section{Establishment of optimal $R A$ dose}

All-trans RA (Sigma-Aldrich) was thoroughly mixed with sunflower oil (Yonca Gida San AS, Manisa, Turkey) immediately before use. Fish were anaesthetised in $40 \mathrm{mg} / 1$ benzocaine, and, gently held in a wet towel, before a volume ranging from 80 to $95 \mu \mathrm{l}$ oil was injected i.p. with a 23 gauge needle and disposable syringes. Doses administered were 0 , $10,100,250$ and $500 \mu \mathrm{g}$ RA/g fish with three fish tested per dose. Each dose was administered to three fish. Fish were individually marked with a silicon dye (Visible Implant Elastomer, Northwest Marine Technology, Shaw Island, WA, USA) and kept in the same tank for 5 days. After which the fish were anaesthetised using benzocaine $(40 \mathrm{mg} / \mathrm{l})$ and blood was collected from the caudal vessels by puncture with heparinised syringes. Blood samples were kept on ice until centrifugation $(1500 \mathrm{~g}, 10 \mathrm{~min})$. Plasma was flash-frozen in liquid $\mathrm{N}_{2}$ and stored at $-80{ }^{\circ} \mathrm{C}$ until analysis. Liver was excised and a standardised section immediately flash-frozen in liquid $\mathrm{N}_{2}$. Gene expression of the RA catabolising enzyme cyp26 was used as a marker for RA exposure.

\section{$R A$ and CTR treatment}

CTR $\left(1 \alpha, 25(\mathrm{OH})_{2} \mathrm{D}_{3}\right)$ and all-trans RA were thoroughly mixed with sunflower oil to obtain two stock solutions; $3 \mu \mathrm{g}$ $\mathrm{CTR} / \mathrm{ml}$ oil and $30 \mathrm{mg} \mathrm{RA} / \mathrm{ml}$ oil. Four treatments were 
tested: 1) oil (Control group), 2) CTR in oil (CTR group), 3) $\mathrm{RA}$ in oil ( $R A$ group) and 4) RA plus CTR ( $A-C T R$ group) in oil. A volume between 80 and $170 \mu \mathrm{l}$ was injected i.p. Predicted vitamin doses were $10 \mathrm{ng}$ CTR/g fish (Qiu et al. 2007) and $100 \mu \mathrm{g}$ RA/g fish (based on the experiment for establishing optimal RA dose described above). Fish were individually marked with silicon dye and experimental groups were kept in the same tank throughout the experiment. Fish were sampled prior to injection (day 0) and at days 3, 5 and 7 after injection and sampled as above. At day 0 , individual plasma samples from five fish were taken $(n=5)$ but at days 3 , 5 and 7 plasma from nine fish per treatment were pooled into three pools $(n=3)$. Liver, gill and vertebral spine from nine fish per treatment were collected and immediately flash frozen on liquid $\mathrm{N}_{2}$. Gill epithelium was scraped off the arch using a microscope slide. The vertebral spine was excised and all adhering tissue removed.

\section{$C a$ and $P$ influx in gut sacs}

A functional assay of $\mathrm{Ca}$ and $\mathrm{P}$ absorption through an in vitro experiment exposing gut sacs to labelled $\mathrm{Ca}$ or $\mathrm{P}$ served as a marker of protein expression, e.g. Ca channels in intestine. Since cold-water fish often show a considerable delay between gene transcription and protein expression, timing of sampling is of essence. In a study by Qiu et al (2007), after a single i.p. injection of CTR, expression of an epithelial Ca channel, VDR and a zinc transporter in rainbow trout gill was at a maximum 5 days after injection, suggesting that the protein expression would be at maximum subsequent to day 5 . Accordingly, at day 7 after injection, the digestive tract was excised from the section immediately distal to the pyloric caecae and transferred to ice-cold aerated Cortland saline (composition in mM: NaCl, $124 ; \mathrm{KCl}, 5 \cdot 1 ; \mathrm{CaCl}_{2} \cdot 2 \mathrm{H}_{2} \mathrm{O}, 1$; $\mathrm{MgSO}_{4}, 1 \cdot 9 ; \mathrm{NaHCO}_{3}, 11 \cdot 9 ; \mathrm{NaH}_{2} \mathrm{PO}_{4} \cdot \mathrm{H}_{2} \mathrm{O}, 2 \cdot 9$; glucose, 5.5; (Mommsen \& Hochachka 1994). The method for intestinal sac uptake studies followed that described by Nadella et al. (2006). The excised intestine was cut in two with the anterior (for Ca uptake determination) and posterior (for phosphorous) sections being defined by the obvious morphological distinctions between these gut regions. Measurement of unidirectional ion movement started within $2 \mathrm{~h}$ of gut dissection.

A flanged catheter was tied in place at one end of the intestinal sacs, and ice-cold Cortland saline used to flush the sacs of food remains. The open end was then tied with suture thread. Radionuclide containing solutions were introduced into the sacs through the catheter. These solutions consisted of either ${ }^{33} \mathrm{P}$ or ${ }^{45} \mathrm{Ca}$ (ARC, St Louis, MO, USA) at a radioisotope concentration of $370 \mathrm{kBq} / \mathrm{ml}$ Cortland saline. The anterior sac always contained ${ }^{45} \mathrm{Ca}$, while the posterior contained ${ }^{33} \mathrm{P}$. Solutions were added via the catheter until the gut sacs appeared firm, but not taut $(\sim 20-70 \mu$ per sac, varying with sac size). Catheters were heat sealed, and the sac placed in $4.5 \mathrm{ml}$ of bathing solution (Cortland saline) in a $5 \mathrm{ml}$ plastic tube, itself situated in a water bath with temperature controlled at $12{ }^{\circ} \mathrm{C}\left( \pm 1^{\circ} \mathrm{C}\right)$. Each tube was bubbled with a $95 \% \mathrm{O}_{2}, 5 \% \mathrm{CO}_{2}$ gas mixture. After $2 \mathrm{~h}$, the sacs were removed, the suture undone and the sacs flushed with $\sim 10$ volumes of cold rinse solution, containing either $\sim 1 \mathrm{M} \mathrm{Ca}$ (for ${ }^{45} \mathrm{Ca}$ ) or $\sim 1 \mathrm{M}$ phosphate (for ${ }^{33} \mathrm{P}$ ), to displace adsorbed radionuclide. Sacs were then split longitudinally, blotted gently on wet tissue and the mucosal surface scraped with a microscope slide. The intestinal surface area was estimated as described by Grosell \& Jensen (1999).

Intestinal scrapings and the remainder of the intestinal tissue were then digested $\left(1 \mathrm{M} \mathrm{HNO}_{3}\right)$ for 2 days at room temperature, neutralised $(1 \mathrm{M} \mathrm{NaOH})$, before addition of scintillation fluor $(10 \mathrm{ml}$; Ecoscint A; National Diagnostics, Atlanta, GA, USA). Duplicate $2 \mathrm{ml}$ samples of the bathing medium were taken to assess ${ }^{45} \mathrm{Ca}$ or ${ }^{33} \mathrm{P}$ specific activities. Radionuclide activity was estimated by liquid scintillation counting (1900 TR Tri-Carb, Packard, Ramsey, MN, USA), with quenching corrected via an external standards ratio method. Unidirectional fluxes $\left(\mathrm{nmol} / \mathrm{cm}^{2}\right.$ per $\left.\mathrm{h}\right)$ were calculated on a surface area-specific basis, over an hour using initial specific activity (c.p.m./nmol). Absorbed minerals were defined as those accumulated in the intestinal tissue and in the serosal medium (Nadella et al. 2006).

\section{Analysis of plasma retinoids, CTR, magnesium, $C a$ and $P$}

Plasma was analysed for retinoids, CTR, magnesium $(\mathrm{Mg})$, $\mathrm{Ca}$ and P. RA, 4-oxo RA and retinol were analysed by AS Vitas (Oslo, Norway) with a LC/MS/MS (Gundersen et al. 2007). CTR was measured by the Radboud University Nijmegen Medical Centre according to van Hoof et al. (1993). Plasma was diluted 250-fold with demineralised water, and total $\mathrm{Ca}$ and $\mathrm{P}$ were measured by Inductively Coupled Plasma Atomic Emission Spectrophotometry (ICPAES, Plasma IL200; Thermo Electron, Waltham, MA, USA).

\section{RNA extraction}

Frozen samples of liver and gill were homogenised in Trizol using MagNA Lyser Green Beads (Roche). Vertebra samples were homogenised in liquid $\mathrm{N}_{2}$ using a mortar and pestle prior to Trizol extraction. Total RNA was purified using Trizol extraction and subjected to DNAse treatment (DNAfreeTM, Ambion, Austin, TX, USA). RNA quantity and quality $\left(A_{260 / 280}\right)$ was assessed using a NanoDrop ND100 spectrophotometer (NanoDrop Technologies, Wilmington, DE, USA) and by gel electrophoresis using an Agilent 2100 Bioanalyzer (Agilent Technologies, Palo Alto, CA, USA).

\section{Reverse transcription-PCR}

cDNA was prepared from $125 \mathrm{ng}$ RNA using the TaqMan Reverse Transcription Reagents kit (Applied Biosystems, Foster City, CA, USA) with Oligo $\mathrm{d}(\mathrm{T})_{16}$ primers in a total reaction volume of $30 \mu \mathrm{l}$. The reaction mixtures were incubated at $25^{\circ} \mathrm{C}$ for $10 \mathrm{~min}, 48^{\circ} \mathrm{C}$ for $60 \mathrm{~min}$ and $95^{\circ} \mathrm{C}$ 
for $5 \mathrm{~min}$ followed by a decrease to $4{ }^{\circ} \mathrm{C}$. Reverse transcription (RT)-PCR efficiency was validated using a six-point calibration curve from serial dilutions of one RNA sample from 1000 to $15 \mathrm{ng}$ per reaction. 'No template' and 'no activity' controls were made for each RT master mix.

\section{Q-PCR}

Real-time qPCR primers for ecac, cyp24 and cyp26 were designed using Primer Express 2.0 software (Applied Biosystems). Primers for col1a2, mgp and alp were from Wargelius et al. (2009), and primers for ef $1 a_{A}$ and arp were from Olsvik et al. $(2005,2007)$ respectively. Primers were based on salmonid sequences when available or on sequences from related species (Table 1, primer sequences). Real-time qPCR was performed using SYBRGreen PCR Master mix (Applied Biosystems), 2.5 $\mu \mathrm{RT}$ template and gene specific primers $(0.9 \mu \mathrm{M})$ and run on the ABI Prism 7000 Sequence Detection system (Applied Biosystems). All samples were run in triplicate with accompanying "no template' and 'no activity' controls. Reaction conditions were $95^{\circ} \mathrm{C}$ for $10 \mathrm{~min}, 40$ cycles of $95^{\circ} \mathrm{C}$ for $15 \mathrm{~s}$ and $60^{\circ} \mathrm{C}$ for $1 \mathrm{~min}$ and a final dissociation step with $95^{\circ} \mathrm{C}$ for $15 \mathrm{~s}$, $60{ }^{\circ} \mathrm{C}$ for $20 \mathrm{~s}$ and $95^{\circ} \mathrm{C}$ for $15 \mathrm{~s}$. All Q-PCR products yielded a single-peak melting curve indicating that no primer-dimer formation occurred.

\section{Normalisation of gene expression and statistical analyses}

Elongation factor $1 \mathrm{~A}\left(e f 1 a_{A}\right)$ and acidic ribosomal protein (arp) were used as reference genes. The stability of these genes was estimated using the geNorm VBA applet for Microsoft Excel (Vandesompele et al. 2002). ef1 $a_{A}$ proved to be the more stable and all investigated genes are presented relative to $e f 1 a_{A}$. Assessment of statistically significant differences between treatments for gene expression data was performed using non-parametric Kruskal-Wallis ANOVA followed by the Mann-Whitney U-test. Regression analysis was performed for correlation between $\mathrm{P}$ and $\mathrm{Ca}$ uptake in gut sacs using GraphPad Prism 5.02 (GraphPad software, La Jolla, CA, USA). Assessment of statistically significant differences between treatments for plasma values and the gut sac experiment were determined by one-way ANOVA, followed by a least significant difference post-hoc test at the $\alpha=0 \cdot 05$ level.

\section{Results}

\section{Optimal RA dose}

A hyperbolic dose-response relation (correlation $r^{2}=0.90$ ) for injected RA dose and the resulting cyp26 mRNA expression was observed (Fig. 1). Plasma RA concentrations ranged from $30 \mathrm{pM}$ in untreated control fish to $50 \mathrm{nM}$ in fish injected with $500 \mu \mathrm{g} \mathrm{RA} / \mathrm{g}$ body weight (BW). cyp26 mRNA expression increased with increasing RA concentrations with a $\sim 430$-fold higher expression in groups injected with $500 \mu \mathrm{g} \mathrm{RA} / \mathrm{g} \mathrm{BW}$ compared to those fish injected with pure sunflower oil. Furthermore, no all-trans or 13-cis 4-oxo RA, products from Cyp26 RA catabolism, were seen in the groups given 0 or $10 \mu \mathrm{g} \mathrm{RA} / \mathrm{g} \mathrm{BW}$, while groups exposed to 100, 250 and $500 \mu \mathrm{g} \mathrm{RA} / \mathrm{g} \mathrm{BW}$ showed increasing 4-oxo RA concentrations in plasma with increasing RA exposure (data not shown). cyp26 expression plateaued at doses above $100 \mu \mathrm{g} / \mathrm{kg} \mathrm{BW}$ and therefore $100 \mu \mathrm{g}$ $\mathrm{RA} / \mathrm{g} \mathrm{BW}$ was chosen as the RA dose for combination treatment.

Table 1 Primer sequences for matrix Gla protein (mgp), collagen $1 \alpha 2$ (col1a2), alkaline phosphatase (alp), epithelial calcium channel (ecac), 25-hydroxyvitamin $\mathrm{D}_{3}$-24-hydroxylase (cyp24), retinoic acid-metabolising enzyme (cyp26), elongation factor 1A (ef1a $a_{A}$ and acidic ribosomal protein (arp) in Atlantic salmon (S. salar L.)

Primer sequence $\left(5^{\prime} \rightarrow 3^{\prime}\right)$

Primer
col1a 2
mgp
ecac
alp
cyp26
cyp24
arp
ef1 $1 a_{A}$

Fw: GAG GGT GGA TGC AGG TGT GT

Rv: TAC TGG ATC GAC CCC AAC CA

Fw: GAA AGC ACA GAA TCC TTT GAA GAT GT

Rv: GTG GAC TCT GTG GGT TGA TGA A

Fw: TGG GTG CCC TGG TTA TTC TG

Rv: ATC GCA TAG GCA ATA AGA ATG ACA

Fw: CTA CAC GCC AAG AGG GAA CAC

Rv: GGT AAA GGG TTT CTG GTC CAC AT

Fw: GAG GAC TCG TCG CGT TTT AAC T

Rv: TTG GCG AAC TCT TTC CCT ACA

Fw: GGA GAC CAT TTG CTT AGT GC

Rv: CCA AAT GTG CTC ATC ATC G

Fw: TCA TCC AAT TGC TGG ATG ACT ATC

Rv: CTT CCC ACG CAA GGA CAG A

Fw: CCC CTC CAG GAC GTT TAC AAA

Rv: CAC ACG GCC CAC AGG TAC A
Accession number

CA064459

AY182239

AY256348

CO472235

CK890206

AY526907

AY255630

AF321836 


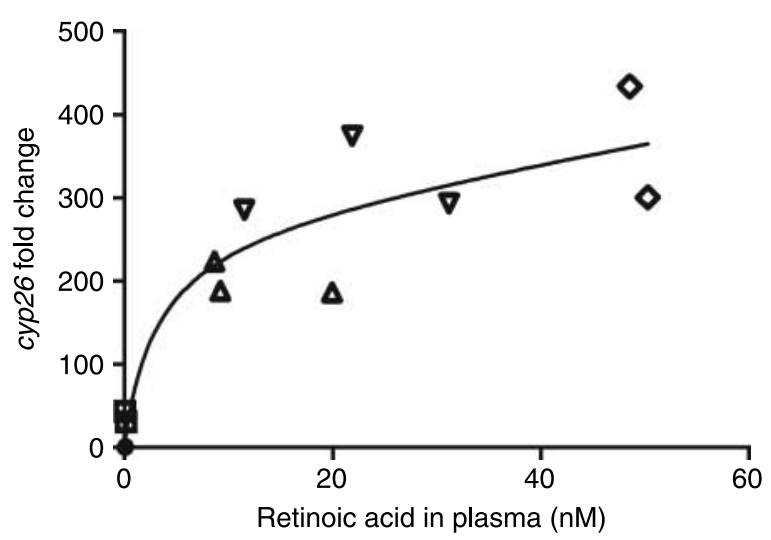

Figure 1 Gene expression (fold difference compared with nontreated fish) of cyp26 relative to elongation factor $1 \mathrm{~A}\left(\right.$ ef $\left.1 \mathrm{a}_{A}\right)$ and plasma retinoic acid $(\mathrm{nM})$ in Atlantic salmon (Salmo salar L.) 5 days after i.p. injection of $0(\bullet), 10(\square), 100(\nabla), 250(\Delta)$ and $500(\diamond)$ $\mu \mathrm{g} / \mathrm{g}$ fish of all-trans retinoic acid in sunflower oil.

\section{$R A$ and $C T R$ treatment}

I.p. injection of CTR reduced plasma CTR levels approximately fourfold $(P<0 \cdot 05)$ after 3 days compared to controls (Fig. 2). Although still approximately twofold lower than controls $(P<0 \cdot 05)$, CTR plasma levels increased again after 5 days and were not significantly different from controls at day 7. Plasma VA metabolites were not affected by CTR injection. RA injection decreased plasma CTR approximately fivefold after 5 and 7 days $(P<0 \cdot 05)$ but not after 3 days. In the RA-CTR group, plasma CTR levels decreased approximately four- to sixfold at day 3,5 and 7. All-trans retinol plasma concentration (the plasma transport form of retinoids), was significantly $(P<0 \cdot 05)$ lower, while plasma 9-cis, 13-cis and all-trans RA levels and the RA degradation products 13-cis and all-trans 4-oxo RA were significantly

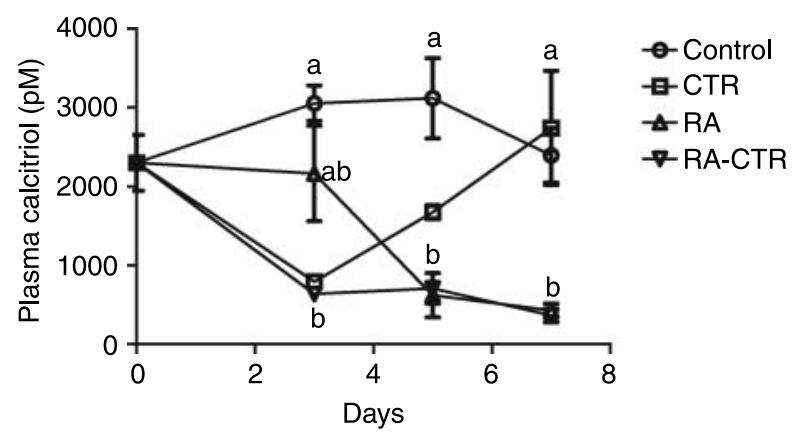

Figure 2 Plasma values of calcitriol (pM) in Atlantic salmon (Salmo salar L.) prior to and at 3, 5 and 7 days after i.p. injection of pure sunflower oil (Control), calcitriol in sunflower oil (CTR), retinoic acid in sunflower oil (RA) or CTR and RA in sunflower oil (RA-CTR). Data reported as means \pm S.E.M., $n=3$, where each replicate represents a pool of plasma from three fish. Different superscript letters denote significant differences within each time point, $P<0 \cdot 05$ (ANOVA).
$(P<0 \cdot 05)$ higher at days 3,5 and 7 in the $R A$ and $R A-C T R$ groups (Table 2). There were no differences among groups in plasma total $\mathrm{Ca}, \mathrm{Mg}$ or $\mathrm{P}_{\mathrm{i}}$ at any time point (Table 2).

\section{Gene expression}

Figure 3 shows the mRNA expression of mgp, col1a2 and alp in bone, ecac in gill and cyp24 in liver. CTR injection reduced $m g p$ mRNA expression $1 \cdot 4$-fold $(P<0 \cdot 05)$ relative to controls at day 5 after injection. RA- and RACTR-injection resulted in a $3 \cdot 8$ - and $3 \cdot 2$-fold reduction $(P<0 \cdot 05)$ at day 5 and $3 \cdot 0-$ and $3 \cdot 9$-fold reduction $(P<0 \cdot 05)$ at day 7 compared to controls. CTR injection reduced col1a2 mRNA expression $1 \cdot 4$-fold compared to controls $(P<0 \cdot 05)$ at day 7 after injection. RA and RA-CTR injection reduced col1a2 mRNA expression $2 \cdot 4$ - and $1 \cdot 8$-fold $(P<0 \cdot .05)$ relative to control expression at day 5 , and by $3 \cdot 4$ - and $5 \cdot 1-$ fold $(P<0 \cdot 05)$ at day 7 . CTR injection reduced alp expression $1 \cdot 3$-fold $(P<0 \cdot 05)$ at day 5 . Conversely, injection of RA increased alp expression $1 \cdot 3$-fold relative to controls at day $5(P<0 \cdot 05)$. CTR and RA-CTR injection did not induce expression of ecac in gills. RA injection increased expression of ecac 1.3-fold compared to control expression at day $7(P<0 \cdot 05)$. Expression of cyp24 was not affected by any of the treatments at any tested day.

\section{$\mathrm{Ca}$ and $\mathrm{P}$ uptake}

$\mathrm{P}$ uptake across gut sacs 7 days after injection (Fig. 4) ranged between 2 and $50 \mathrm{nmol} / \mathrm{cm}^{2}$ per hour and was not affected by any of the treatments. Ca uptake ranged between 1 and $20 \mathrm{nmol} / \mathrm{h}$ per $\mathrm{cm}^{2}$ and was enhanced significantly in RACTR treated fish compared to both the controls $(P<0 \cdot 05)$ and CTR group $(P<0 \cdot 05)$. In RA treated fish, $\mathrm{P}$ uptake and $\mathrm{Ca}$ uptake was significantly and positively correlated $\left(P<0 \cdot 05, r^{2}=0 \cdot 49\right)$, while no such correlation was seen for the other experimental treatments (data not shown).

\section{Discussion}

The effect of RA on plasma CTR and mRNA expression of selected genes provided strong evidence for an interaction between VA and VD in Atlantic salmon. We showed that artificially induced (by i.p. injection) elevations in plasma RA interfered with plasma CTR and bone physiology. We base this conclusion on three key observations. First, increased RA plasma levels reduced plasma CTR levels. Second, the altered plasma RA and CTR levels resulted in predictable alterations in mRNA expression of several genes involved in bone formation. Third, intestinal $\mathrm{Ca}$ absorption increased in RA treated fish, possibly indicating increased demand of this mineral. We will elaborate on these findings below.

Injection of CTR resulted in unexpected dynamics of this VD metabolite in vivo, with CTR plasma levels dropping below control values 3 days after CTR injection. 
Table 2 Plasma values of retinol, retinoic acid, $\mathrm{Mg}$, total $\mathrm{Ca}$ and $\mathrm{P}_{\mathrm{i}}$ in Atlantic salmon (Salmo salar $\mathrm{L}$.) prior to and 3, 5 and 7 days after after i.p. injection of pure sunflower oil (Control), calcitriol in sunflower oil (CTR), retinoic acid in sunflower oil (RA) or CTR and RA in sunflower oil (RA-CTR). Data reported as means \pm s.E.M., $n=3$, where each replicate represents a pool of plasma from three fish

\begin{tabular}{|c|c|c|c|c|c|}
\hline & & Days post & atment & & \\
\hline & Treatment & 0 & 3 & 5 & 7 \\
\hline $\begin{array}{l}\text { Analyte } \\
\text { All-trans retinol }(\mathrm{nmol} / \mathrm{l})\end{array}$ & $\begin{array}{l}\text { Control } \\
\text { CTR } \\
\text { RA } \\
\text { RA-CTR }\end{array}$ & $142 \pm 39$ & $\begin{array}{l}148 \pm 16^{a} \\
151 \pm 1^{a} \\
12 \pm 1^{b} \\
12 \pm 3^{b}\end{array}$ & $\begin{array}{l}181 \pm 46^{\mathrm{a}} \\
166 \pm 16^{\mathrm{a}} \\
7 \pm 1^{\mathrm{b}} \\
10 \pm 2^{\mathrm{b}}\end{array}$ & $\begin{array}{l}154 \pm 15^{\mathrm{a}} \\
115 \pm 16^{\mathrm{a}} \\
11 \pm 2^{\mathrm{b}} \\
10 \pm 1^{\mathrm{b}}\end{array}$ \\
\hline 13-cis retinoic acid ( $\mathrm{nmol} / \mathrm{l})$ & $\begin{array}{l}\text { Control } \\
\text { CTR } \\
\text { RA } \\
\text { RA-CTR }\end{array}$ & $2 \cdot 8 \pm 0 \cdot 4$ & $\begin{array}{l}9 \pm 3^{b} \\
14 \pm 4^{b} \\
1616 \pm 396^{a} \\
1812 \pm 656^{a}\end{array}$ & $\begin{array}{l}4 \pm 1^{\mathrm{b}} \\
5 \pm 1^{\mathrm{b}} \\
2455 \pm 696^{\mathrm{a}} \\
2982 \pm 302^{\mathrm{a}}\end{array}$ & $\begin{array}{l}3 \pm 1^{\mathrm{b}} \\
4 \pm 2^{\mathrm{b}} \\
454 \pm 270^{\mathrm{a}} \\
613 \pm 299^{\mathrm{a}}\end{array}$ \\
\hline 9-cis retinoic acid ( $\mathrm{nmol} / \mathrm{l})$ & $\begin{array}{l}\text { Control } \\
\text { CTR } \\
\text { RA } \\
\text { RA-CTR }\end{array}$ & $1 \cdot 4 \pm 0 \cdot 1$ & $\begin{array}{l}\text { ND } \\
1 \cdot 4 \pm 0 \cdot 1^{+} \\
413 \pm 87 \\
442 \pm 110\end{array}$ & $\begin{array}{l}\mathrm{ND} \\
2^{\ddagger} \\
478 \pm 135 \\
579 \pm 54\end{array}$ & $\begin{array}{l}1 \cdot 2^{\ddagger} \\
1 \cdot 2^{\ddagger} \\
150 \pm 91 \\
161 \pm 75\end{array}$ \\
\hline All-trans retinoic acid (nmol /l) & $\begin{array}{l}\text { Control } \\
\text { CTR } \\
\text { RA } \\
\text { RA-CTR }\end{array}$ & $0 \cdot 6 \pm 0 \cdot 1$ & $\begin{array}{l}19 \pm 3^{\mathrm{b}} \\
12 \pm 2^{\mathrm{b}} \\
51480 \pm 5118^{\mathrm{a}} \\
54031 \pm 5591^{\mathrm{a}}\end{array}$ & $\begin{array}{l}11 \pm 4^{\mathrm{b}} \\
20 \pm 9^{\mathrm{b}} \\
44157 \pm 6549^{\mathrm{a}} \\
46043 \pm 5399^{\mathrm{a}}\end{array}$ & $\begin{array}{l}5 \pm 1^{b} \\
8 \pm 6^{b} \\
14825 \pm 7119^{a} \\
15544 \pm 4620^{a}\end{array}$ \\
\hline 13-cis 4-oxo retinoic acid ( $\mathrm{nmol} / \mathrm{l})$ & $\begin{array}{l}\text { Control } \\
\text { CTR } \\
\text { RA } \\
\text { RA-CTR }\end{array}$ & ND & $\begin{array}{l}\text { ND } \\
\text { ND } \\
9 \pm 1 \\
9 \pm 2\end{array}$ & $\begin{array}{l}\text { ND } \\
\text { ND } \\
21 \pm 4 \\
26 \pm 4\end{array}$ & $\begin{array}{l}1^{\neq} \\
\mathrm{ND} \\
9 \pm 7^{+} \\
6 \pm 2^{+}\end{array}$ \\
\hline All-trans 4-oxo retinoic acid (nmol/l) & $\begin{array}{l}\text { Control } \\
\text { CTR } \\
\text { RA } \\
\text { RA-CTR }\end{array}$ & ND & $\begin{array}{l}\text { ND } \\
\text { ND } \\
120 \pm 27 \\
124 \pm 29\end{array}$ & $\begin{array}{l}\text { ND } \\
\text { ND } \\
175 \pm 31 \\
234 \pm 64\end{array}$ & $\begin{array}{l}1^{\ddagger} \\
\mathrm{ND} \\
56 \pm 32 \\
61 \pm 24\end{array}$ \\
\hline Total $\mathrm{Ca}^{2+}(\mathrm{mol} / \mathrm{l})$ & $\begin{array}{l}\text { Control } \\
\text { CTR } \\
\text { RA } \\
\text { RA-CTR }\end{array}$ & NA & $\begin{array}{l}2149 \pm 18^{*} \\
2134 \pm 7^{*} \\
2159 \pm 51^{*} \\
2245 \pm 82^{*}\end{array}$ & $\begin{array}{l}2261 \pm 34 \\
2137 \pm 56 \\
2161 \pm 81 \\
2136 \pm 75\end{array}$ & $\begin{array}{l}2229 \pm 48 \\
2249 \pm 36 \\
2198 \pm 27 \\
2199 \pm 39\end{array}$ \\
\hline $\mathrm{Mg}(\mathrm{mol} / \mathrm{l})$ & $\begin{array}{l}\text { Control } \\
\text { CTR } \\
\text { RA } \\
\text { RA-CTR }\end{array}$ & NA & $\begin{array}{l}272 \pm 1^{*} \\
270 \pm 3^{*} \\
296 \pm 22^{*} \\
298 \pm 27^{*}\end{array}$ & $\begin{array}{l}294 \pm 2 \\
263 \pm 8 \\
274 \pm 12 \\
277 \pm 17\end{array}$ & $\begin{array}{l}286 \pm 12 \\
285 \pm 6 \\
272 \pm 7 \\
277 \pm 3\end{array}$ \\
\hline$P_{\mathrm{i}}(\mathrm{mol} / \mathrm{l})$ & $\begin{array}{l}\text { Control } \\
\text { CTR } \\
\text { RA } \\
\text { RA-CTR }\end{array}$ & NA & $\begin{array}{l}1797 \pm 55^{*} \\
1599 \pm 171^{*} \\
1490 \pm 453^{*} \\
1696 \pm 54^{*}\end{array}$ & $\begin{array}{l}2026 \pm 164 \\
1656 \pm 145 \\
1851 \pm 52 \\
1951 \pm 194\end{array}$ & $\begin{array}{l}1760 \pm 257 \\
1491 \pm 338 \\
1986 \pm 104 \\
1038 \pm 431\end{array}$ \\
\hline
\end{tabular}

NA, not available; ND, not detected. Different superscript letters denote significant differences in each time point, $P<0 \cdot 05$ (ANOVA).

$n=1$, not detected.

$n=2$, not detected.

${ }^{*} n=2$, loss of sample.

Circulating CTR plasma levels are regulated by both synthesis and degradation. The enzyme primarily responsible for CTR synthesis (from $25(\mathrm{OH}) \mathrm{D}_{3}$ ) in liver and kidney) is 25-hydroxyvitamin D 1 $\alpha$-hydroxylase (CYP27B1). CTR degradation to biologically inactive products, e.g. $1,24,25(\mathrm{OH})_{3} \mathrm{D}_{3}$, is mediated primarily through 25-hydroxyvitamin D-24-hydroxylase (CYP24; Sakaki et al. 2005). CTR degradation through CYP24 has a multifactorial regulation, being modulated by RA, CTR (Zou et al. 1997, Reinhardt et al. 1999) and parathyroid hormone (PTH; Zierold et al. 2001) for example. (Lechner et al. 2007) demonstrated that CTR treatment of cells derived from human colon, prostate and mammary tissue diminished $c y p 27 b 1$ transcription and elevated cyp24 mRNA levels. We were not able to demonstrate any increase in CYP24 at mRNA level at 3, 5 or 7 days. It is possible that changes in cyp24 expression occurred prior to day 3 , and would not have been detected under our sampling regime. 

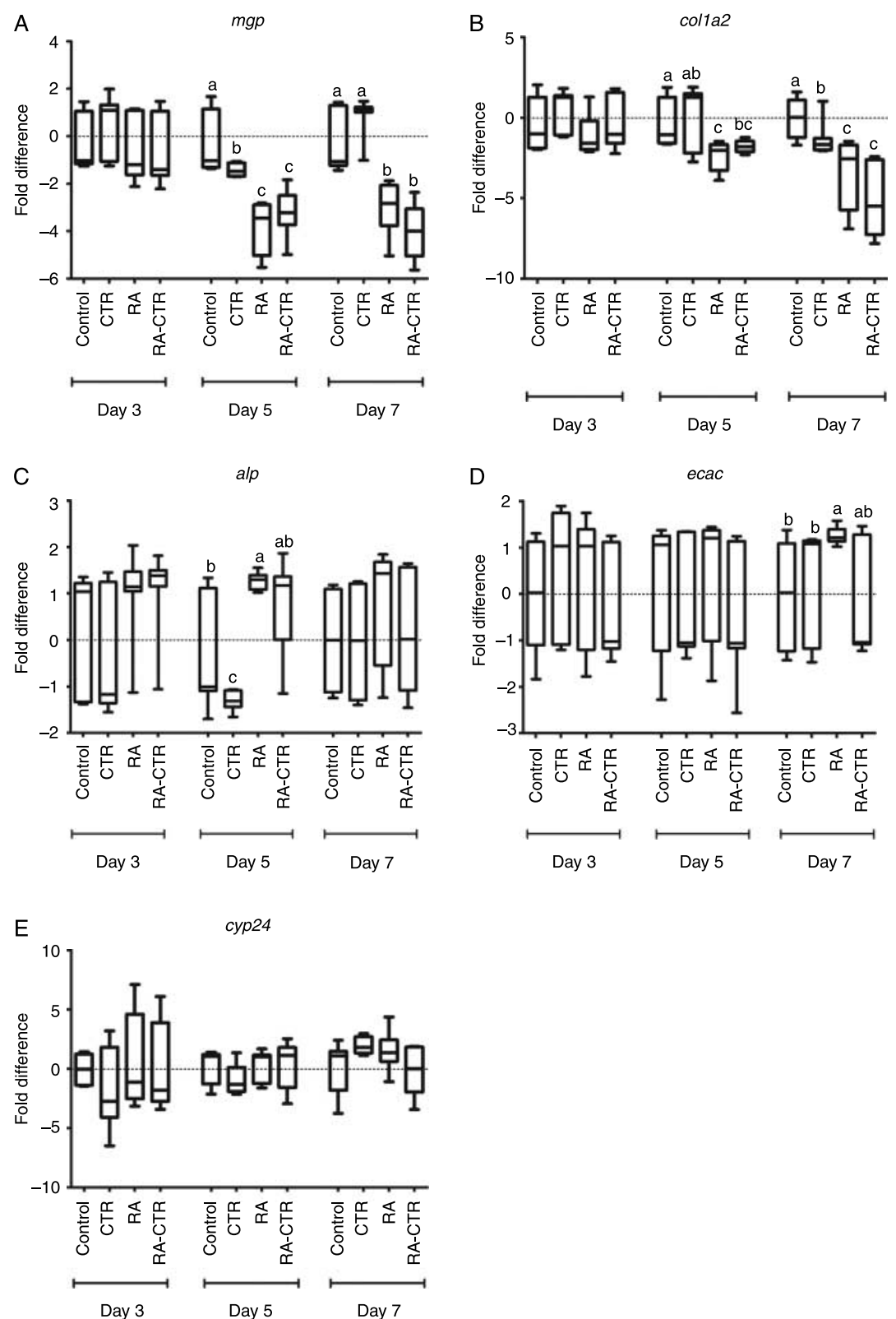

Figure 3 Gene expression (fold difference relative to Control) in Atlantic salmon (Salmo salar L.) at 3, 5 and 7 days after i.p. injection of pure sunflower oil (Control), calcitriol in sunflower oil (CTR), retinoic acid in sunflower oil (RA) or calcitriol and retinoic acid in sunflower oil (RA-CTR). (A) Matrix Gla protein (mgp) in bone; (B) collagen 1a chain 2 (col1a2) in bone; (C) alkaline phosphatase (alp) in bone; (D) epithelial calcium channel (ecac) in gills and ecyp24 in liver. Data presented as median (horizontal line), 95\% confidence interval (box) and min-max values (whiskers), $n=9$. Different superscript letters denote significant differences within each time point, $P<0 \cdot 05$ (Kruskal-Wallis ANOVA).

Injection of RA resulted in a predictable VA profile. After injection, plasma RA levels increased quickly initially, and decreased slowly during the following days. Plasma RA is broken down by the RA-specific CYP26 (Luu et al. 2001). Indeed, transcription of cyp26 was increased in RA-injected fish when establishing optimal RA dose (Fig. 1).
An important oxidation product of the Cyp26 mediated degradation of RA is 4-oxo RA (Chithalen et al. 2002). This metabolite was elevated in RA- and RA-CTR-injected fish (Table 2), and indicates that pathways for regulating excess RA concentrations had been activated. Furthermore, the availability of the RA precursor retinol was reduced 14-fold in 


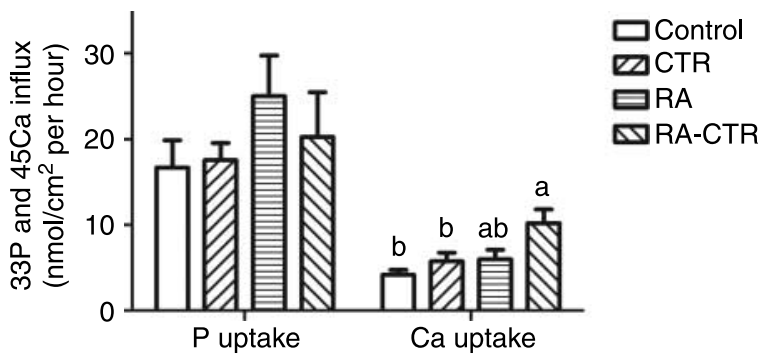

Figure 4 Unidirectional influx $\left(\mathrm{nmol} / \mathrm{cm}^{2}\right.$ per h) of phosphorus and calcium across gut sacs isolated from Atlantic salmon (Salmo salar L.) 7 days after i.p. injection of pure sunflower oil (Control), calcitriol in sunflower oil (CTR), retinoic acid in sunflower oil (RA) or calcitriol and retinoic acid in sunflower oil (RA-CTR). Bars reported as means ( \pm S.E.M.), $n=9$. Different superscript letters denote significant differences-within each treatment, $P<0 \cdot 05$ (ANOVA).

plasma of the RA- and RA-CTR-injected fish (Table 2) suggesting that mechanisms for reducing production of RA through retinol oxidation were down-regulated.

A negative association between high plasma retinol and plasma $25(\mathrm{OH}) \mathrm{D}_{3}$ concentrations has been found in human subjects (Mata-Granados et al. 2008). In our study, a persistently elevated plasma RA level in Atlantic salmon decreased plasma CTR levels by at least 80\%. All-trans RA and 9-cis RA are potent stimulators of Cyp24 expression in vivo in mice (Allegretto et al. 1995). A similar mechanism in salmon could explain the decrease in plasma CTR levels at day 5 and 7 in RA-treated fish. The fastest clearance of plasma CTR levels was observed in the RA-CTR group, a possible additive effect of both RA and CTR on cyp24. Accordingly, a twofold increase in rat renal CYP24 activity when co-dosing CTR and RA compared to CTR alone has previously been reported (Reinhardt et al. 1999).

The extracellular matrix proteins MGP and collagen perform a regulatory and a structural role respectively. In fish species, data on $m g p$ transcription are scant. In the teleost, Sparus auratus, a negative RARE in the promoter region of the $m g p$ gene has been identified and inhibition of $m g p$ transcription by RA has been demonstrated (Conceicao et al. 2008). In the current study, transcription of $m g p$ was significantly inhibited in the CTR, RA- and RA-CTR groups. The results obtained in the current study are, to our knowledge, the first to describe an effect of CTR on mgp in a teleost fish. Numerous studies have investigated the effect of CTR on collagen type- I formation, and both up- and downregulation of col1 has been found, depending on species and model system (van Driel et al. 2004). The decrease in col1a2 transcription in the CTR-group at day 7 can be explained by lower plasma CTR values at days 3 and 5 . $\mathrm{RA}$ is an inhibitor of collagen synthesis and the reduction in colla2 transcription is in line with other studies (Wang et al. 2002).

alp is a known marker of preosteoblasts and osteoblasts in both mammals (Whyte 1994) and fish (Witten 1997) and is commonly used as a marker of mineralisation processes.
Transcription of alp is stimulated by both RA (Heath et al. 1992) and CTR (Whyte 1994). Conversely, the reduction of CTR in plasma transiently reduced the expression of alp in the CTR-group in our study. The low plasma concentration of CTR in the RA- and RA-CTR groups possibly counteracted the effect of RA, and only a small increase in expression of alp ( $\sim 1 \cdot 3$-fold $)$ was seen in these groups. For the RA-groups a picture emerged whereby matrix protein transcription ( $m g p$ and col1a2) was inhibited and transcription of bone alp (important for mineralisation of the matrix) was stimulated. However, a caveat applies. Gene expression data do not necessarily reflect the actual protein expression or activity. If mineralisation does increase under RA treatment, then the recruitment of $\mathrm{Ca}, \mathrm{P}$ and $\mathrm{Mg}$ from plasma might be expected. These are the primary minerals required to deposit apatites. However, no changes in plasma levels of these minerals were seen, which we do not find surprising given the strict homeostatic control of plasma levels of these elements, especially $\mathrm{Ca}$, in vertebrates. Also in fish, plasma Ca levels are tightly regulated by a variety of hormones including stanniocalcin (Pierson et al. 2004), PTH-related protein (Abbink et al. 2007), calcitonin (Najib \& Martine 1996), prolactin (Flik et al. 1984) and VD. Increased deposition of $\mathrm{Ca}$ (and also to a lesser extent $\mathrm{P}$ and $\mathrm{Mg}$ ) would quickly be compensated for by increased uptake from the environment. The gills are an important organ for Ca uptake from the water (Flik \& Verbost 1993), and in many fish are more important than the intestinal uptake route. A gene likely to be involved in transcellular Ca transport is the ecac (Hoenderop et al. 1999); a member of the Transient Receptor Potential Vanilloid, TRPV, class of ion channels (Hoenderop et al. 2002). In rainbow trout, the branchial ecac responds to variations in external $\mathrm{Ca}$ concentrations, and is pivotal in regulating $\mathrm{Ca}$ influx via the gills (Shahsavarani \& Perry 2006). Qiu \& Hogstrand (2004) identified two VDREs in the promoter region of branchial ecac of pufferfish (Fugu rubripes) and later demonstrated an increased expression of ecac in rainbow trout (Oncorhynchus mykiss) gills after i.p. injection of CTR (Qiu et al. 2007). The increase in ecac mRNA expression in the gill in the RA-group in the current study could relate to an increased $\mathrm{Ca}$ demand. Lending support to changes in mineral metabolism, the absorption of $\mathrm{Ca}$ across the intestine was increased after 7 days in the RA-CTR groups (Fig. 4). A positive correlation between intestinal $\mathrm{P}$ uptake and $\mathrm{Ca}$ uptake in RA-treated fish was also observed, supporting the hypothesis of an increased need for $\mathrm{Ca}$ and/or P. Since no major changes in plasma levels of $\mathrm{Ca}$ and $\mathrm{P}$ occurred, either the excretion of the minerals had increased or more minerals were deposited. The increase in alp transcription in these same groups would be in line with the latter process. Taking into account the apparent decrease in matrix formation, constant high plasma levels of RA in Atlantic salmon may result in abnormal bone growth and could explain bone malformations seen in fish overfed VA (Ørnsrud et al. 2002). 
Although i.p. injection of high RA doses can be considered a non-physiological situation, this study does provide mechanistic evidence for an interaction between RA and CTR that may form a basis for an understanding of some types of bone deformities seen in aquaculture. In support of this, we recently found evidence that feeding graded doses of VA as retinol for a prolonged period of time decreases plasma CTR, increases Alp activity in bone, increases mineral content of bone and causes bone deformities in Atlantic salmon (Ørnsrud et al. 2008).

The data from this study indicate a dual effect of RA on bone. While RA inhibits matrix formation, it also appears to activate genes involved in matrix mineralisation. Suppression of plasma CTR levels could partly explain the effects of VA on bone. The results suggest a more integrated approach when studying the effect of fat-soluble vitamins on bone could be a key to a more complete understanding of bone physiology.

\section{Declaration of interest}

The authors declare that there is no conflict of interest that could be perceived as prejudicing the impartiality of the research reported.

\section{Funding}

This work was supported by the Norwegian Research Council (project no. 153472).

\section{Acknowledgements}

We gratefully acknowledge the technical assistance of Tom Spanings, Hari Rudra and Rolf Hetlelid Olsen. Many thanks to Dr Anna Wargelius for constructive criticism and for helping out with the primer design and validation.

\section{References}

Abbink W, Hang XM, Guerreiro PM, Spanings FAT, Ross HA, Canario AVM \& Flik G 2007 Parathyroid hormone-related protein and calcium regulation in vitamin D-deficient sea bream (Sparus auratus). Journal of Endocrinology 193 473-480.

Aburto A \& Britton WM 1998a Effects and interactions of dietary levels of vitamin $\mathrm{A}$ and $\mathrm{E}$ and cholecalciferol in broiler chickens. Poultry Science $\mathbf{7 7}$ 666-673.

Aburto A \& Britton WM $1998 b$ Effects of different levels of vitamins A and E on the utilization of cholecalciferol by broiler chickens. Poultry Science $\mathbf{7 7}$ 570-577.

Allegretto EA, Shevde N, Zou AB, Howell SR, Boehm MF, Hollis BW \& Pike JW 1995 Retinoid-X-receptor acts as a hormone-receptor in vivo to induce a key metabolic enzyme for 1,25-dihydroxyvitamin- $\mathrm{D}_{3}$. Journal of Biological Chemistry 270 23906-23909.

Chithalen JV, Luu L, Petkovich PM \& Jones G 2002 HPLC-MS/MS analysis of the products generated from all-trans retinoic acid using recombinant human CYP26A. Journal of Lipid Research 43 1133-1142.

Clark I \& Bassett AL 1962 The amelioration of hypervitaminosis D in rats with vitamin A. Journal of Experimental Medicine 115 147-156.
Cohen-Tanugi A \& Forest N 1998 Retinoic acid supresses the osteogenic differentiation capacity of murine osteoblast-like 3/A/1D-1M cell cultures. Differentiation 63 115-123.

Conceicao N, Laize V, Simoes B, Pombinho AR \& Cancela ML 2008 Retinoic acid is a negative regulator of matrix Gla protein gene expression in teleost fish Sparus aurata. Biochimica et Biophysica Acta: Gene Regulatory Mechanisms 1779 28-39.

Dedi J, Takeuchi T, Seikai T \& Watanabe T 1995 Hypervitaminosis and safe levels of vitamin A for larval flounder (Paralichthys olivaceus) fed Artemia nauplii. Aquaculture 133 135-146.

Dickson I \& Walls J 1985 Vitamin A and bone formation - effect of an excess of retinol on bone-collagen synthesis in vitro. Biochemical Journal 226 789-795.

Van Driel M, Pols HAP \& Van Leuween JPTM 2004 Osteoblast differentiation and control by vitamin $\mathrm{D}$ and vitamin $\mathrm{D}$ metabolites. Current Pharmaceutical Design 10 2535-2555.

Erben RG, Scutt AM, Miao D, Kollenkirchen U \& Haberey M 1997 Shortterm treatment of rats with high dose 1,25-dihydroxyvitamin $\mathrm{D}_{3}$ stimulates bone formation and increases number of osteoblast precursor cells in bone marrow. Endocrinology 138 4629-4635.

Fenwick JC, Smith K, Smith J \& Flik G 1984 Effect of various vitamin-D analogs on plasma calcium and phosphorus and intestinal calciumabsorption in fed and unfed american eels, Anguilla rostrata. General and Comparative Endocrinology 55 398-404.

Fenwick JC, Davison W \& Forster ME 1994 In vivo calcitropic effect of some vitamin-D compounds in the marine antarctic teleost, Pagothenia bernacchii. Fish Physiology and Biochemistry 12 479-484.

Flik G \& Verbost PM 1993 Calcium-transport in fish gills and intestine. Journal of Experimental Biology 184 17-29.

Flik G, Bonga SEW \& Fenwick JC $1984 \mathrm{Ca}^{2+}$-dependent phosphatase and $\mathrm{Ca}^{2+}$-dependent Atpase activities in plasma-membranes of eel gill epithelium. 3. Stimulation of branchial high-affinity $\mathrm{Ca}^{2+}$-Atpase activity during prolactin-induced hypercalcemia in american eels. Comparative Biochemistry and Physiology. Part B, Biochemistry and Molecular Biology 79 521-524.

Frankel TL, Seshadri MS, Mcdowall DB \& Cornish CJ 1986 Hypervitaminosis A and calcium-regulating hormones in the rat. Journal of Nutrition $116578-587$.

Grosell M \& Jensen $\mathrm{F} 1999 \mathrm{NO}_{2}^{-}$uptake and $\mathrm{HCO}_{3}^{-}$excretion in the intestine of the European flounder (Platichthys flesus). Journal of Experimental Biology 202 2103-2110.

Gundersen TE, Bastani NE \& Blomhoff R 2007 Quantitative highthroughput determination of endogenous retinoids in human plasma using triple-stage liquid chromatography/tandem mass spectrometry. Rapid Communications in Mass Spectrometry 21 1176-1186.

Heath JK, Suva LJ, Yoon KG, Kiledjian M, Martin TJ \& Rodan GA 1992 Retinoic acid stimulates transcriptional activity from the alkalinephosphatase promoter in the immortalized rat calvarial cell-line, Rct-1. Molecular Endocrinology 6 636-646.

Hoenderop JGJ, Van Der Kemp A, Hartog A, Van De Graaf SFJ, Van Os CH, Willems P \& Bindels RJM 1999 Molecular identification of the apical $\mathrm{Ca}^{2+}$ channel in 1,25-dihydroxyvitamin $\mathrm{D}_{3}$-responsive epithelia. Journal of Biological Chemistry 274 8375-8378.

Hoenderop JGJ, Nilius B \& Bindels RJM 2002 ECaC: the gatekeeper of transepithelial $\mathrm{Ca}^{2+}$ transport. Biochimica et Biophysica Acta: Proteins and Proteomics 1600 6-11.

Van Hoof HJC, Swinkels LMJW, Van Stevenhagen JJ, Van Den Berg H, Ross HA \& Benraad TJ 1993 Advantages of paper chromatography as a preparative step in the assay of 1,25-dihydroxyvitamin D. Journal of Chromatography: Biomedical Applications 621 33-39.

Johansson S \& Melhus H 2001 Vitamin A antagonizes calcium response to vitamin D in man. Journal of Bone and Mineral Research 16 1899-1905.

Kim HT \& Chen TL 1989 1,25-Dihydroxyvitamin-D ${ }_{3}$ interaction with dexamethasone and retinoic acid - effects on procollagen messenger ribonucleic-acid levels in rat osteoblast-like cells. Molecular Endocrinology 3 97-104. 
Lechner D, Kallay E \& Cross HS 2007 1 $\alpha, 25$-Dihydroxyvitamin $\mathrm{D}_{3}$ downregulates CYP27B1 and induces CYP24A1 in colon cells. Molecular and Cellular Endocrinology 263 55-64.

Van Leeuwen JPTM, Van Driel M, Van Den Bemd GJCM \& Pols HAP 2001 Vitamin D control of osteoblast function and bone extracellular matrix mineralisation. Critical Reviews in Eukaryotic Gene Expression 11 199-226.

Luu L, Ramshaw H, Tahayato A, Stuart A, Jones G, White J \& Petkovich M 2001 Regulation of retinoic acid metabolism. Advances in Enzyme Regulation 41 159-175.

Mata-Granados JM, De Castro MDL \& Gomez JMQ 2008 Inappropriate serum levels of retinol, $\alpha$-tocopherol, 25 hydroxyvitamin $\mathrm{D}_{3}$ and 24,25 dihydroxyvitamin $\mathrm{D}_{3}$ levels in healthy Spanish adults: simultaneous assessment by HPLC. Clinical Biochemistry 41 676-680.

Metz AL, Walser MM \& Olson WG 1985 The interaction of dietary vitamin A and D related to skeletal development in the turkey poult. Journal of Nutrition 115 929-935.

Mommsen TP \& Hochachka PW 1994 Buffered salt solutions, culture media and tissue homogenization buffers. In Biochemistry and Molecular Biology of Fishes, pp 649-657. Eds PW Hochachka \& TP Mommsen. Geneva: Elsevier.

Nadella S, Grosell M \& Wood C 2006 Physical characterization of highaffinity gastrointestinal $\mathrm{Cu}$ transport in vitro in freshwater rainbow trout Oncorhynchus mykiss. Journal of Comparative Physiology B 176 793-806.

Najib L \& Martine FP 1996 Adaptation of rainbow trout to seawater: changes in calcitonin gene-related peptide levels are associated with an increase in hormone-receptor interaction in gill membranes. General and Comparative Endocrinology 102 274-280.

Olsvik P, Lie K, Jordal A-E, Nilsen T \& Hordvik I 2005 Evaluation of potential reference genes in real-time RT-PCR studies of Atlantic salmon. BMC Molecular Biology 621.

Olsvik PA, Lie KK, Sæle O \& Sanden M 2007 Spatial transcription of CYP1A in fish liver. BMC Physiology 712.

Ørnsrud R, Graff LE, Høie S, Totland GK \& Hemre GI 2002 Hypervitaminosis A in first-feeding fry of the Atlantic salmon (Salmo salar L.). Aquaculture Nutrition 8 7-13.

Ørnsrud R, Lock E-J, Fjelldal PG \& Waagbø R 2008 Establishing san upper level of vitamin A in Atlantic salmon (Salmo salar). XIII International symposium on fish nutrition and feeding. Florianopolis, Brasil.

Pathrose P, Barmina O, Chang CY, Mcdonnell DP, Shevde NK \& Pike JW 2002 Inhibition of 1,25-dihydroxyvitamin $\mathrm{D}_{3}$-dependent transcription by synthetic LXXLL peptide antagonists that target the activation domains of the vitamin D and retinoid X receptors. Journal of Bone and Mineral Research 17 2196-2205

Petkovich PM, Heersche JNM, Aubin JE \& Jones G 1986 Retinoic acidinduced changes in 1,25-dihydroxy-vitamin- $\mathrm{D}_{3}$ receptor levels in tumor and nontumor cells derived from rat bone. Journal of Bone and Mineral Research 1 141-141.

Pierson PM, Lamers A, Flik G \& Mayer-Gostan N 2004 The stress axis, stanniocalcin, and ion balance in rainbow trout. General and Comparative Endocrinology 137 263-271.

Qiu A \& Hogstrand C 2004 Functional characterisation and genomic analysis of an epithelial calcium channel (ECaC) from pufferfish, Fugu rubripes. Gene 342 113-123.

Qiu A, Glover CN \& Hogstrand C 2007 Regulation of branchial zinc uptake by 1 [alpha],25- $(\mathrm{OH}) 2 \mathrm{D}_{3}$ in rainbow trout and associated changes in expression of ZIP1 and ECaC. Aquatic Toxicology 84 142-152.

Reinhardt TA, Koszewski NJ, Omdahl J \& Horst RL 1999 1,25dihydroxyvitamin $\mathrm{D}_{3}$ and 9-cis-retinoids are synergistic regulators of 24-hydroxylase activity in the rat and 1,25-dihydroxyvitamin $\mathrm{D}_{3}$ alters retinoic acid metabolism in vivo. Archives of Biochemistry and Biophysics 368 244-248.

Rohde CM \& Deluca H 2003 Bone resorption activity of all-trans retinoic acid is independent of vitamin D in rats. Journal of Nutrition 133 777-783.

Rohde CM \& Deluca HF 2005 All-trans retinoic acid antagonizes the action of calciferol and its active metabolite, 1,25-dihydroxycholecalciferol, in rats. Journal of Nutrition 135 1647-1652.

Rohde CM, Manatt M, Clagett-Dame M \& Deluca HF 1999 Vitamin A antagonizes the action of vitamin D in rats. Journal of Nutrition 129 2246-2250.

Sakaki T, Kagawa N, Yamamoto K \& Inouye K 2005 Metabolism of vitamin $\mathrm{D}_{3}$ by cytochromes $\mathrm{P} 450$. Frontiers in Bioscience 10 119-134.

Shahsavarani A \& Perry SF 2006 Hormonal and environmental regulation of epithelial calcium channel in gill of rainbow trout (Oncorhynchus mykiss). American Journal of Physiology. Regulatory, Integrative and Comparative Physiology 291 R1490-R1498.

Suzuki S, Koga M, Takaoka K, Ono K \& Sato B 1993 Effects of retinoic acid on steroid and vitamin $\mathrm{D}_{3}$ receptors in cultured mouse osteosarcoma cells. Bone 14 7-12.

Vandesompele J, De Preter K, Pattyn F, Poppe B, Van Roy N, De Paepe A \& Speleman F 2002 Accurate normalization of real-time quantitative RT-PCR data by geometric averaging of multiple internal control genes. Genome Biology 3 DOI:10.1186/gb-2002-3-7-research0034.

Varghese S, Rydziel S, Jeffrey JJ \& Canalis E 1994 Regulation of interstitial collagenase expression and collagen degradation by retinoic acid in bone cells. Endocrinology 134 2438-2444.

Wang L, Tankersley LR, Tang G, Potter JJ \& Mezcy E 2002 Regulation of the murine $\alpha_{2}(\mathrm{I})$ collagen promoter by retinoic acid and retinoid $\mathrm{X}$ receptors. Archives of Biochemistry and Biophysics 401 262-270.

Wargelius A, Fjelldal PG, Nordgarden U \& Hansen T 2009 Continuous light affects mineralization and delays osteoid incorporation in vertebral bone of Atlantic salmon (Salmo salar L.). Journal of Experimental Biology 212 656-661.

Wendelaar Bonga SE, Lammers PI \& Vandermeij JCA 1983 Effects of 1,25and 24,25-dihydroxyvitamin- $\mathrm{D}_{3}$ on bone-formation in the cichlid teleost Sarotherodon mossambicus. Cell and Tissue Research 228 117-126.

Whyte MP 1994 Hypophosphatasia and the role of alkaline-phosphatase in skeletal mineralization. Endocrine Reviews 15 439-461.

Witten PE 1997 Enzyme histochemical characteristics of osteoblasts and mononucleated osteoclasts in a teleost fish with acellular bone (Oreochromis niloticus, Cichlidae). Cell and Tissue Research 287 591-599.

Wronski TJ, Halloran BP, Bikle DD, Globus RK \& Morey-Holton ER 1986 Chronic administration of 1,25-dihydroxyvitamin $\mathrm{D}_{3}$ : increased bone but impaired mineralisation. Endocrinology 119 2580-2585.

Zierold C, Mings JA \& Deluca H 2001 Parathyroid hormone regulates 25-hydroxyvitamin $\mathrm{D}_{3}$-24-hydroxylase $\mathrm{mRNA}$ by altering its stability. PNAS 98 13572-13576.

Zou A, Elgort MG \& Allegretto EA 1997 Retinoid X receptor (RXR) ligands activate the human 25-hydroxyvitamin $\mathrm{D}_{3}$-24-hydroxylase promoter via RXR heterodimer binding to two vitamin $\mathrm{D}$ responsive elements and elicit additive effetcs with 1, 25 dihydroxyvitamin $\mathrm{D}_{3}$. Journal of Biological Chemistry 272 19027-19034.

Received in final form 12 June 2009

Accepted 16 June 2009

Made available online as an Accepted Preprint 16 June 2009 